\title{
THE PEACEFUL RISE OF CHINA AND IT'S IMPLICATIONS FOR EAST ASIA
}

\author{
By Jusuf Wanandi (Indonesia)
}

\section{Introduction}

It would be instructive to begin this examination with some history in the relationship between China with East Asia in order to get a clear sense of how much have changed in that relationship for the good of the region as a whole and its future development.

For a long time China has been the most powerful country in the region, where she has "suzerainty" over many other countries, especially in her surrounding. The relationship implies recognition by the other countries of China's influence and primacy. They regularly pay tribute to her, but beyond that, they can do whatever they want.

This relationship ended when Western colonial powers occupied parts of the region in the early and mid of the $19^{\text {th }}$ century. Since then China was also pressured to open up, and parts of China was colonized through several wars, starting with the occupation of Hong Kong after China lost in the Opium War in the mid of the $19^{\text {th }}$ century.

China became a republic in the beginning of the $20^{\text {th }}$ century, and after a very debilitating period of civil wars and eight years of war against Japan, the Communist Party has regained complete independence for China and control overall parts of China. But then, a series of crises happened, such as the Great Leap Forward and the Cultural Revolution, which hampered China's development and modernization. Only since 1979 have China's modernization and development efforts been made in earnest under the courageous and farsighted leadership of Deng Xiao Ping.

Throughout her history, there was only one period where China was in an alliance, namely from 1950 to 1960 with the former USSR. At all other times, she has been alone, because she was "the Middle Kingdom", and relationships with others were never equal. As an important Communist country in the 1950's she was revolutionary and until the 1970's she was exporting revolution into the region, especially into the South East Asia region through solidarity and support to local Communist Parties.

These activities stopped since Deng Xiao Ping embarked on China's modernization programs, because China needs a peaceful environment and 
good relations with the world and especially with the East Asian region as the nearest environment of China. Since then China has normalized relations with every country in the region, last being Indonesia, Singapore, and Brunei Darussalam in 1990. China has rejoined the international community especially through the U.N. system and regional institutions, starting with PECC and APEC in the economic field, followed by ARF and CSCAP in the politico-security field, in which she is very active.

Now she is also actively promoting and taking a lead in the ASEAN + 3 (China, Japan and South Korea) process that could be transformed into an East Asian Community in the future. This is the most promising arrangement for the region, including China. China has given a lot of attention to the U.N. Arms Control and Disarmament efforts. She also has joined the WTO.

While in the beginning China was very reluctant to do more beyond issues concerning her own national interests (in particular the Taiwan problem) at the U.N., now she is taking a more active role, although not as pronounced yet, as a P-5 member. In regional affairs, she is much more willing to participate, although at the beginning there has been some worry about the rules and institutions that were established before she became a member, but China has adapted to them and is also influencing their further development. This only showed that she has gradually become a status quo power, willing to liven up and accept existing multilateral responsibilities and obligations, according to the prevailing rules and institutions in the region.

These policies are in line with her national interest globally and regionally, namely multilateralism. The multipolar world that she desires, however, has been postponed by U.S. supremacy, although the possibility of a "concert of power" has also been proposed by the U.S. (in her National Security Strategy Review of September 2002). But the U.S. has not shown any intention or effort lo implement that idea.

In conclusion, it can be said that China has transformed itself from being a revolutionary power from the 1950 s to the 1970 s into a status quo power. While she was reluctant before to get involved fully in international and regional institutions, now she is completely involved and in some instances is even willing to take the lead. That augurs well for the region because her national interest is parallel with a peaceful and dynamic region, among others where regional institutions will play an important role. 


\section{China's Current Relations with the Region and Their Future Implications}

In the last ten years, China has become an economic challenge. This is completely a different challenge from a China that was in a revolutionary mood. Economic challenges are not a zero sum game, as is the case in the security field. China's economic rise could be beneficial to all sides if handled well. It is the win-win proposition that the region should promote.

In the beginning, this challenge was seen as threatening because jobs were being taken away as the manufacturing capabilities of the countries in the region are moving into China. Besides that most of the capital, investment and transfer of technology meant for East Asian countries are instead going to China. This is not only a problem for the labor intensive industries, especially in Indonesia, and other lower industrializing countries, but also for the other high value-added industries in the industrializing economies like Korea, Taiwan and Singapore.

The private sectors in many of those countries have prepared for this development earlier, and have tried to find their own niches in China. They have done it either by becoming part of China's manufacturing activities, exporting parts and components to be assembled there, or producing other things in which they have the advantage of having natural resources, or a slightly cheaper labor because of favorable exchange rates. They also engage in production networks by investing in China and export from China, using parts and components coming from other East Asian countries. It is a real possibility that China will become a great power on her own right, as she could grow by at least $7-8 \%$ annually in the foreseeable future.

But China also faces great challenges: the problems of NPLs and the banking restructuring have yet to be faced. The unemployment problems and the discrepancies in income between the coastal regions and the inland are still increasing. Some economic problems will continue to put great pressures on the government. The overheated economy this year is another short-term challenge to be faced.

On top of the socio-economic problems, there are also challenges to open the political system and introduce greater accountability and transparency of government policies. These important tasks are not easy to deliver. But this is recognized by the Chinese leadership, and they are being tried out selectively such as giving greater authority to the Central Committee for oversight in the policy making process of the Politburo, or 
direct elections for rural heads with independent candidates, or a greater role by the People's Congress in laying down outline of policies.

Some relaxation of the tight control of the media has been taken. The leadership is trying to experiment with limited private and even foreign ownership in media production. These are undertaken both for political reasons, i.e. to become more effective and credible to their own people, and economic reasons, i.e. to consolidate and enhance profit making in the media sector.

These are reasons why China needs an environment that is peaceful and friendly lo enable her to overcome those problems and challenges. This is exactly what she is doing. China has developed friendly relations with the surrounding countries through regional agreements and cooperation.

One such agreement is the Shanghai Security Cooperation Agreement, which laid down the basic security relation between Russia and China and four Central Asian countries, in their fight against Islamic terrorism along her Northwest border.

China also has laid down a good neighborhood policy with India although not all of the border cases have been solved. With ASEAN in South East Asia, she has created good relations through economic and political-security cooperation.

And the six-party talks on the Korean problem have created a new regional instrument in Northeast Asia that could be used in overcoming future- potential conflicts and differences in-the sub-region, which very much lacks regional instruments, due to a historic animosity between China and Korea on the one side and Japan on the other side.

Last but not least, China-U.S. relations have been kept on a stable basis due to the anti-terrorist cooperation. This does not mean that things will always be smooth between the two, especially on the question of reunification with Taiwan. China always needs to be prepared for changes in the mood of U.S. public opinion and the strength of the right wing in the Republican Party to throw new impediments in the relationship because of their policies in supporting Taiwan's independence. Besides relations with the US, there is still the unfinished problem of her relations with Japan, because full normalization has not yet happened, due to their different interpretations and attitudes towards the China-Japan War between 1937 and 1945.

Japan believes that she has made her apologies to China, but China is of the view that this was never done fully, including an assurance to not repeating 
the same mistakes in the future. The visit of PM Koizumi to the Yasukuni Shrine in Tokyo, which also includes the Memorial for the War victims, including war criminals, has never been acceptable to the Chinese. Therefore, China continues to protest.

But on the other hand, in the past five years or so the two economies have to a large extent become complementary. In the field of trade both have become each other biggest trading partners and Japan's investments into China, with the corresponding transfer of technology, have increased by leaps and bounds.

Both sides are also cooperating enthusiastically in the East Asian Community building efforts.

The region is facing for the first time a strong China and a strong Japan at the same time, and the challenge is how to make sure that they will not oppose each other. Especially, since both are becoming full fledged great powers in the near future. China has come up very fast as an economic and political security power, while Japan is becoming a "normal" country with a possible full-fledged role in the security field, and is the second largest economy. This will be realized if the Japan's constitution will be amended in the next few years. Her involvement in Iraq already showed the willingness to involve the SDF in conflicts situation in and out of the region.

It will be good for the region if Japan will confine SDFs involvement either in U.N. peacekeeping and peace building efforts or in supporting US operations, concurred upon by the international community or by U.S. friends and allies.

Among China's small or medium sized neighbors such as South Korea and the ASEAN countries, thus far, China has been at her best, although complaints of big power syndrome will always be there, but they are not serious. China is really trying her utmost to cultivate relations with ASEAN despite the setback ASEAN has experienced since the financial crisis of 1997. ASEAN is thankful about the support from China and is trying very hard show its appreciation,

On Taiwan, all ASEAN countries support China, and since every member has their own problems of separatism or insurgency to face, the support is sincere and real. But there must be more dialogues and intellectual exchanges between China and ASEAN (and South Korea) about Chinese policies on Taiwan. Until now, China always considers this an internal affair of China and does not want to talk about her policies, except hammering only on the one China policy. 
Since the Taiwan problem has become a regional security issue that concerns all East Asian countries, including ASEAN, China needs to intensify dialogues and exchange of ideas, so that China's policies are better understood. ASEAN members feel that China could be more flexible and give greater space to some Taiwanese scholars to be included in the exchanges. Because if they are being isolated, they will never understand ASEAN's views that essentially support Chinese policies towards Taiwan. Taiwan can create havoc due to her volatile domestic politics or misunderstanding of the policies of East Asian countries towards the reunification issue.

The most important thing for China is to strengthen the support of other countries including East Asian that reject any moves or efforts for Taiwan independence, openly or covertly.

This is especially the case in regard to the USA. who can be influenced by the policies and attitudes of East Asian countries toward Taiwan? China must not get too nervous and overreact to every move or announcement of policies by the Taiwanese government so long as that is not going to be supported by the international community, especially by the USA and by the countries in East Asia.

In the meantime, China should continue to expand and deepen the economic relations with Taiwan, besides efforts for further dialogue with them whenever possible. While doing that the long-term idea of a greater China with Taiwan included has to be kept alive for both the Taiwanese people and the international community.

For China and the region, the East Asian Community is an important vision and at the same time critical to face future challenges of the region. The idea of the Community is for East Asia to have peace, stability and progress. It has three strategic objectives. First is to be able to incorporate China into a regional institution, which will be able to cope with a potential superpower, which China could become in the next few decades without creating problems and anxieties among her neighbors. At the same time, she will deepen her identity as a status quo power. If there is a model in the region, it should be like Indonesia who put herself in a regional entity called ASEAN in order to reassure her neighbors of her peaceful and friendly intentions (following confrontation against Malaysia and Singapore in 1963-1966).

Second is to assist and support the process of normalization between China and Japan, since this is an important factor in East Asian community building. Both should become the leaders of the future community. Third is to be able 
to prevent future confrontations between China and the U.S., if as expected, China on her own right will become another superpower in the longer term, With the regional institution and China's membership in it, it is hoped that the U.S. is willing to accept that China is not a rival or is looking forward for a confrontation against the U.S. It will also give credence to China's attitude as a status quo power who never would challenge the U.S. In fact, they do not have opposing ideologies or values, as was the case with the USSR during the Cold War So far, China also does not have a strategic interest to do so.

Establishing the East Asian Community will be a big challenge because of the region's diversity, which should be considered seriously and should gradually be overcome.

Leadership is another problem because Sino-Japan relations have to be normalized, similar as the case between Germany and France after World War II. Deepening cooperation on the economic front will assist in this effort, and ASEAN's role (with South Korea) should encourage the normalization between them.

Japan as the main ally of the U.S. in the region has a critical role to play in convincing the U.S. about the value of the East Asian Community. All others in East Asia also have to work hard and be creative in convincing the U.S. to accept the idea. The East Asian Community is not against U.S. interest and is supporting U.S. strategic presence in East Asia.

The East Asian Community will adhere to open regionalism and make sure that APEC as the greater entity and where the U.S. is an important member, will also be strengthened at the same time. It also should be stressed that East Asian regionalism should contribute to global governance besides the existence of the two other pillars, namely the U.S. and EU. The process will be based first on economic cooperation, which to a large extent is already a reality in East Asia, and should be expanded step by step into other fields of cooperation, including in the politico-security dimension. It should complement U.S. strategic presence in East Asia.

China has seen this phenomenon of complementation quite clearly, and it has been helpful to the region, especially to South East Asia since the financial crisis of 1997. Although it was in their own national interest not to devalue the Yuan (since they have done it a few years before the crisis), they have been forthcoming and astute in paying close attention to the crisis and have offered some assistance in finance and in commodities. 
This was followed by China's proposal to establish an ASEAN-China FTA to be established, with an early harvest, especially for agricultural products to be exported first to China, from ASEAN. Talks started two years ago and some improvements have happened. It should become a full FTA in 2012.

What is more important for the ASEAN countries is what has happened in reality, namely the huge demand for imports, especially commodities, by China in the last 2-3 years. This has helped ASEAN countries tremendously as the U.S., EU and Japan have been in an economic slowdown or recession. China has absorbed almost all goods that could not be exported to other countries. China has become a life-line for ASEAN exports at least for the last two years. Since the Chinese economy will need to correct itself because of overheating. ASEAN countries should also try to diversify their exports.

In the meantime, on the political field, China has finalized and signed the Code of Conduct on the South China Sea with ASEAN. This is well appreciated by ASEAN and has resulted in a situation of calm in the South China Sea because both sides are restraining themselves and basically are not doing anything unilaterally. Some actions lately by Vietnam and Taiwan are not welcomed by China or any other claimants from ASEAN.

Last year China has made a political coup, when she signed the Treaty of Amity and Cooperation during the ASEAN +3 Summit in Bali. Although it is mostly a political document, it demonstrated China's willingness to strengthen her relations with ASEAN by promising to keep the region peaceful and stable according to an ASEAN regional order, and to solve differences and potential conflicts in a peaceful way.

The other important thing that China has done for East Asia is in taking the lead in the six-party talks to find a peaceful resolution to the nuclear proliferation issue on the Korean Peninsula. Her involvement could help prevent a war from happening when left only to U.S. unilateralism. It also helps prevent North Korea from collapsing, which also could happen if U.S. strong sanctions are implemented, which will create a big problem for China to deal with possibly as many as five millions North Korean refugees in her Northern border.

It may well be that China feels obliged to take leadership in dealing with a problem that is so near to her and to which she might have the biggest influence. Although the talks have not resulted in a peaceful resolution yet, it has open the way for a peaceful resolution because pressures are building up against the North Koreans and they could no more reject it for too long. 
This has given China the self-confidence to play a greater role in the region in the future.

\section{Concluding Remarks}

China's peaceful rise in East Asia has been mostly positive. It is a challenge to others in the region to be able to cope with a rising China especially in the economic sphere.

Although the economic competition creates difficulties, it is a non-zero sum game. China is willing to assist as she has shown this to ASEAN, by importing their goods, creating networks, in developing partnership and in the proposal for an FTA to be completed in 10 years. The politico-security challenge may arise in the more distant future, and revolve around the question of how to accommodate a new super power in the region. This could be made easier if the East Asian Community can be strengthened and will be capable to absorb China in her midst as a status quo super power, which will greatly contribute to peace, stability and progress in the region and the world. 